\title{
Disinfection efficiency of secondary effluents with ultraviolet light in a Mediterranean area
}

\author{
J. Bayo, J. M. Angosto \& P. Ayala \\ Department of Chemical and Environmental Engineering, \\ Technical University of Cartagena, Spain
}

\begin{abstract}
This paper deals with the study of physicochemical and microbiological parameters affecting the disinfection efficiency of secondary effluents in a municipal wastewater treatment plant, for irrigation purposes. There appears to be an important increase in turbidity values as chlorine values increase, due to the conversion of particulate organic carbon into dissolved organic carbon. The nitrification-denitrification processes appear to be sensitive to changes in $\mathrm{pH}$, with a minimum nitrate value in the wastewater when $\mathrm{pH}$ ranged between 7.01 and 8.00. With a similar behaviour, the phosphate removal was conditioned by $\mathrm{pH}$, showing the highest efficiency in the same $\mathrm{pH}$ range. Both anions proved to be strongly correlated. Total coliforms were more UV light resistant than faecal coliforms, after an exposure of $10 \mathrm{~min}$, corresponding to an UV dose of 73 $\mathrm{mJ} / \mathrm{cm}^{2}$. The experimental results for both groups of microorganisms followed first order reaction kinetics, with a gradual flattening at higher UV doses. A total elimination of both indicators would be achieved with doses over $95 \mathrm{~mJ} / \mathrm{cm}^{2}$. A previous step on the treated wastewater would improve its quality before the disinfection process.
\end{abstract}

Keywords: wastewater; ultraviolet; reuse; disinfection.

\section{Introduction}

The use of treated wastewater is considered an important alternative water resource. Although conventional treatments processes, i.e. sedimentation, filtration and activated sludge, are known to remove up to $99 \%$ of microorganisms, it is not sufficient to achieve requirements for wastewater discharge and wastewater reuse [1]. The disinfection treatment is considered to 
be the primary mechanism for the inactivation or destruction of pathogenic organisms, to prevent the spread of waterborne disease to downstream users and the environment. But the water disinfection efficiency depends on several factors: an adequate contact time to ensure a sufficient reduction of microbial pathogens is necessary with chemical water disinfection, and the dose, for ultraviolet (UV) irradiation, defined as the product of intensity and exposure time [2]. The aim of this paper was to determine the UV irradiation dosages required to destroy total and faecal coliforms in a secondary effluent of a wastewater treatment plant (WWTP), for irrigation purposes.

\section{Materials and methods}

\subsection{Sample collection and UV light treatments}

The study was carried out with urban wastewater treated in the WWTP of Cartagena (Spain). It consists of a conventional system, with a primary treatment and two activated-sludge reactors. Water samples from the secondary effluent were collected in sterile glass bottles for microbiological analyses, and in a plastic collector for physicochemical parameter determinations. The UV radiation was applied using a low-pressure UVC lamp of 8 Watts $(400 \mathrm{~mm}$ length and $85 \mathrm{~mm}$ diameter), with a flow-rate from 500 to $1,100 \mathrm{l} / \mathrm{h}$, and a wavelength of $254 \mathrm{~nm}$. The installation was designed to be used with $1,000 \mathrm{ml}$ of sample, irradiated for short periods of 3, 5, 8, and 10 minutes. According to these data, the doses provided were: $22 \mathrm{~mJ} / \mathrm{cm}^{2}, 37 \mathrm{~mJ} / \mathrm{cm}^{2}, 58 \mathrm{~mJ} / \mathrm{cm}^{2}$, and 73 $\mathrm{mJ} / \mathrm{cm}^{2}$, respectively. Before each treatment, lamp was cleaned up with bidistilled water. After the irradiation, samples were ready for microbiological determinations. All disinfection tests were conducted at room temperature.

\subsection{Physicochemical parameters}

A total of 21 samples were analysed for the following physicochemical parameters: $\mathrm{pH}$, conductivity, turbidity, $\mathrm{COD}, \mathrm{BOD}_{5}$, chlorides total chlorine, nitrates and phosphates. Most parameters were determined in conformity with the "Standard Methods for the Examination of Water and Wastewater" [3]. Because water samples had been previously chlorinated in the WWTP, and in order to study the influence of total chlorine on different variables, data were subdivided into three groups: (1) between 0.15 and $0.34 \mathrm{mg} / 1$ of chlorine; (2) between 0.35 and $0.70 \mathrm{mg} / \mathrm{l}$ of chlorine; and (3) between 0.71 and $0.87 \mathrm{mg} / \mathrm{l} \mathrm{of}$ chlorine. In the same way, $\mathrm{pH}$ values were also classified according to three groups: (1) $\leq 7.00$; (2) between 7.01 and 8.00; and (3) $\geq 8.01$.

\subsection{Microbiological parameters}

Total coliforms and faecal coliforms were analysed by means of the membrane filtration method. The membrane filter selected, with a pore size of $0.45 \mu \mathrm{m}$, was always within the acceptable range, i.e., 20-80 colonies of total coliforms, and 
20-60 colonies of faecal coliforms [3]. Tocal coliforms were cultured on Tergitol agar and incubated at $35^{\circ} \mathrm{C}$ for $24 \mathrm{~h}$. Faecal coliforms were cultured in the same media, and incubated at $44{ }^{\circ} \mathrm{C}$ for $24 \mathrm{~h}$. After the incubation period, colonies were counted and the results calculated as colony forming units (cfu) per $100 \mathrm{ml}$ of sample. The surviving number of total and faecal coliforms at each UV dose was investigated, in order to establish the required dose to comply with legislation. Statistical analysis was carried out using Statistical Package for the Social Sciences (SPSS for Windows 11.0). Bivariate associations between different variables measured in the experiment were calculated using a one-way analysis of variance (ANOVA) test, with $95 \%$ confidence interval.

\section{Results and discussion}

\subsection{General observations}

Table 1 shows the main statistic parameters for secondary effluent before treatments with UV light.

Table 1: $\quad$ Statistic description of treated wastewater before irradiations with UV light.

\begin{tabular}{|l|c|c|c|c|}
\hline \multicolumn{1}{|c|}{ Parameters } & Mean & S.D. & Minimum & Maximum \\
\hline $\mathrm{pH}$ & 7.49 & 0.34 & 6.79 & 8.04 \\
\hline Conductivity $(\mu \mathrm{S} / \mathrm{cm})$ & 2,580 & 247 & 2,330 & 3,290 \\
\hline Turbidity $(\mathrm{NTU})$ & 2.16 & 1.04 & 0.63 & 4.70 \\
\hline Chloride $(\mathrm{mg} / \mathrm{l})$ & 498 & 64 & 418 & 706 \\
\hline $\mathrm{COD}(\mathrm{mg} / \mathrm{l})$ & 31 & 6 & 22 & 41 \\
\hline BOD $_{5}(\mathrm{mg} / \mathrm{l})$ & 8 & 4 & 1 & 16 \\
\hline Nitrate $(\mathrm{mg} / \mathrm{l})$ & 5.74 & 4.35 & 0.70 & 16.80 \\
\hline Phosphate $(\mathrm{mg} / \mathrm{l})$ & 1.73 & 0.79 & 0.10 & 5.50 \\
\hline Total coliforms $(\mathrm{UFC} / 100 \mathrm{ml})$ & 170,810 & 276,962 & 0 & $12 \cdot \mathrm{E}^{5}$ \\
\hline $\begin{array}{l}\text { Faecal coliforms }(\mathrm{UFC} / 100 \\
\text { ml) }\end{array}$ & 17,750 & 23,646 & 0 & $8 \cdot \mathrm{E}^{4}$ \\
\hline
\end{tabular}

\subsection{ANOVA analyses for physicochemical parameters}

There appears to be no effect on $\mathrm{pH}$ and conductivity values that can be related to total chlorine in the secondary effluent, since no statistically significant differences could be observed for both parameters. As previously described by other authors [4], and unlike what occurs with chemical disinfectants, both parameters are not significantly influenced by UV treatment. Water samples with the highest chlorine levels (group 3 ) displayed also the highest turbidity values, with statistically significant differences $(F=7.09 ; p<0.01)$, as shown in Figure 1 . This fact has been pointed out by several authors. Van der Toorn [5] indicates that the effect on turbidity can be explained by the conversion of particulate organic carbon into dissolved organic carbon. On the contrary, chlorides 
decreased when chlorine levels increased in the wastewater, with statistically significant differences $(F=9.26, p<0.001)$, indicating a chemical reduction of chlorine compounds into chlorides. $\mathrm{BOD}_{5}$ levels slightly increased with chlorine levels, but without statistical significance. As presented in Table 2, both nitrate and phosphate values decreased with the chlorination of wastewater, with statistically significant differences $(F=4.94, p<0.01$ for nitrates, and $F=7.60$, $p<0.001$ for phosphates). The lowest average value for nitrate levels corresponded to wastewater samples with the highest chlorine levels.

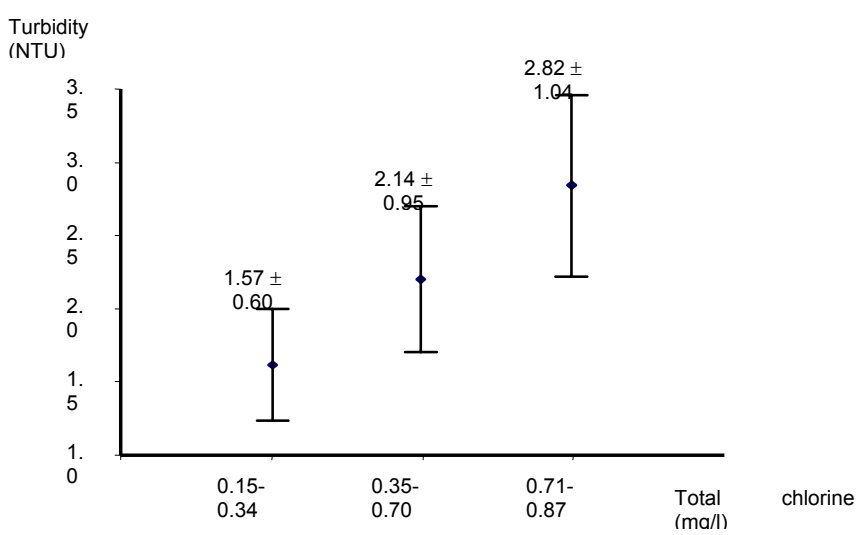

Figure 1: One-way ANOVA plot for turbidity by ranges of total chlorine.

Table 2: One-way ANOVA test for nitrates and phosphates by total chlorine ranges.

\begin{tabular}{|c|c|c|c|c|}
\hline $\begin{array}{c}\text { Total chlorine } \\
\text { ranges }\end{array}$ & $\begin{array}{c}\mathrm{NO}_{3}{ }^{-} \\
(\mathrm{n})\end{array}$ & Mean \pm S.D. $(\mathrm{mg} / \mathrm{l})$ & $\begin{array}{c}\mathrm{PO}_{4}{ }^{3-} \\
(\mathrm{n})\end{array}$ & Mean \pm S.D. (mg/l) \\
\hline & & $F=4.94, p<0.01$ & & $F=7.60, p<0.001$ \\
\hline $1(0.15-0.34 \mathrm{mg} / \mathrm{l})$ & 24 & $6.5 \pm 4.7$ & 24 & $2.4 \pm 1.9$ \\
\hline $2(0.35-0.70 \mathrm{mg} / \mathrm{l})$ & 21 & $7.0 \pm 4.3$ & 21 & $1.9 \pm 1.7$ \\
\hline $3(0.71-0.87 \mathrm{mg} / \mathrm{l})$ & 18 & $3.3 \pm 1.5$ & 18 & $0.6 \pm 0.8$ \\
\hline
\end{tabular}

With the same tendency, the highest average phosphate level $(2.4 \pm 1.9 \mathrm{mg} / \mathrm{l})$ was for the range (1) of total chlorine, with a minimum average value $(0.6 \pm 0.8$ $\mathrm{mg} / \mathrm{l}$ ) for the range (3). As demonstrated by Diyamandoglu et al. [6], both anions could be oxidized in aqueous solution using chlorine gas. The effect of $\mathrm{pH}$ variations on these last parameters was also investigated. The nitrate and phosphate removal efficiency from wastewater according to $\mathrm{pH}$ values is shown in Figures 2 and 3. As it can be observed, these anions displayed the lowest value in treated wastewater when $\mathrm{pH}$ is in the range of 7.01-8.00, with statistically significant differences ( $F=13.21, p<0.001$ for nitrates, $F=11.78, p<0.001)$, and independently from the applied treatment. As stated by different researchers, nitrification-denitrification processes appear to be sensitive to changes in $\mathrm{pH}$ [7]. 
Biological denitrificacion is a process in which nitrate is reduced to nitrogen gas by microorganisms in the absence of dissolved oxygen. Surampalli et al. [8] observed that the rate of this biological process is optimum when $\mathrm{pH}$ is in the range of 7.0-8.0.

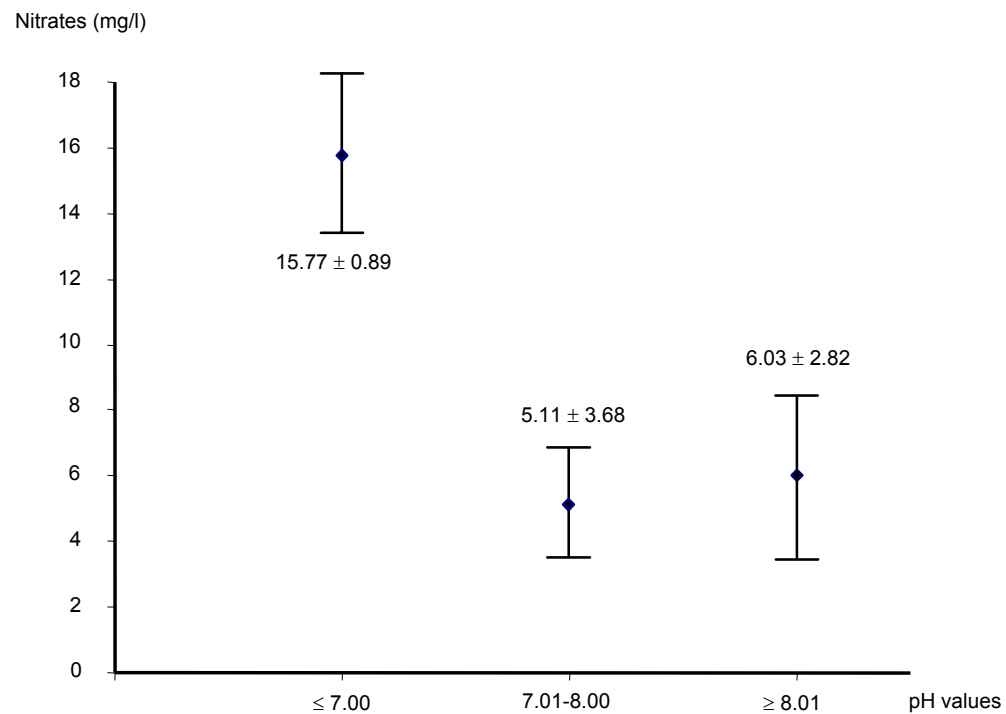

Figure 2: $\quad$ One-way ANOVA plot for nitrates by ranges of $\mathrm{pH}$.

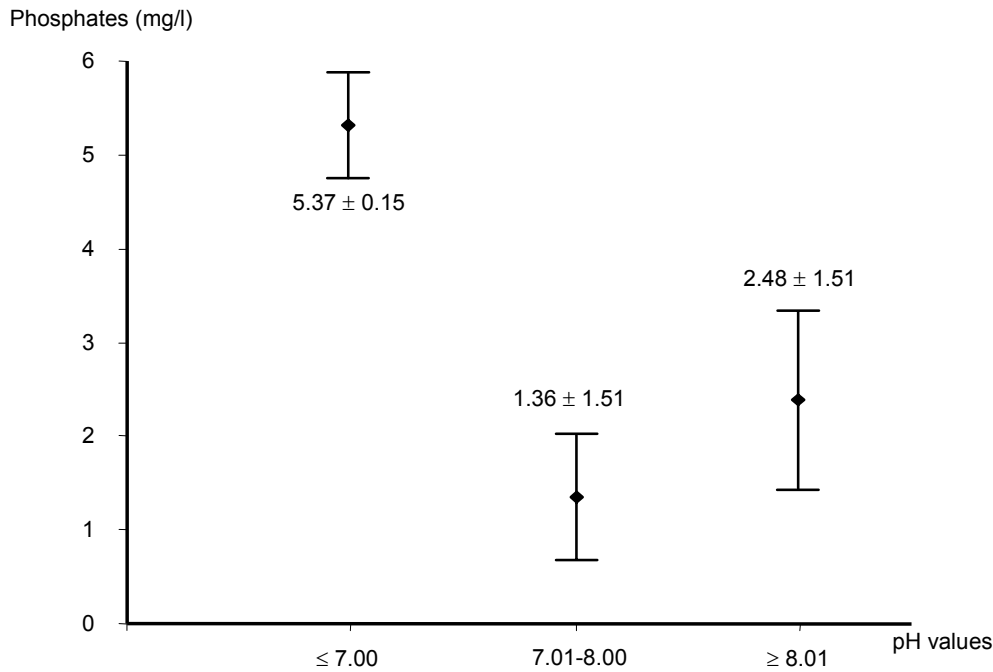

Figure 3: $\quad$ One-way ANOVA plot for phosphates by ranges of $\mathrm{pH}$. 
With a similar behaviour, the phosphate removal is conditioned by $\mathrm{pH}$. It is well-known that phosphate discharged into surface water accelerates eutrophication, which can disturb the balance of organisms present in the water and affect water quality, mainly through the depletion of the oxygen level as the algae decay [9]. As seen in Figure 3, phosphate removal efficiency was directly affected by $\mathrm{pH}$. Irdemez et al. [10], experimenting with the phosphate removal from wastewaters by electrocoagulation with iron plate electrodes, reported that efficiencies of phosphate removal were $93 \%$ in $\mathrm{pH} 7$, and $61 \%$ in $\mathrm{pH} 9$. Hosni et al. [9] have also shown a variation of the percentage of phosphate removal as a function of $\mathrm{pH}$ in synthetic wastewater. Phosphate removal increases with increasing $\mathrm{pH}$, which can be explained by the change of orthophosphate compounds with $\mathrm{pH}$. There was a strong correlation between nitrates and phosphates, with a Pearson's coefficient of $0.845(p<0.01)$. This fact has been previously described in an estuary by Uncles et al. [11].

\subsection{Microbiological determinations}

UV irradiation is the most commonly used alternative to chlorination, with thousands of installations throughout the world, containing open channels equipped with low or medium pressure mercury arc lamps. The success of this system can be attributed to high disinfection efficiency for viruses and bacteria, a minimum of disinfection by-products and low cost [12]. As previously indicated, the efficacy of UV disinfection of water and wastewater depends on the dose. Because biological UV dose-response data are generally log-normally distributed, these data are log-transformed [13]. Figure 4 shows the log reduction

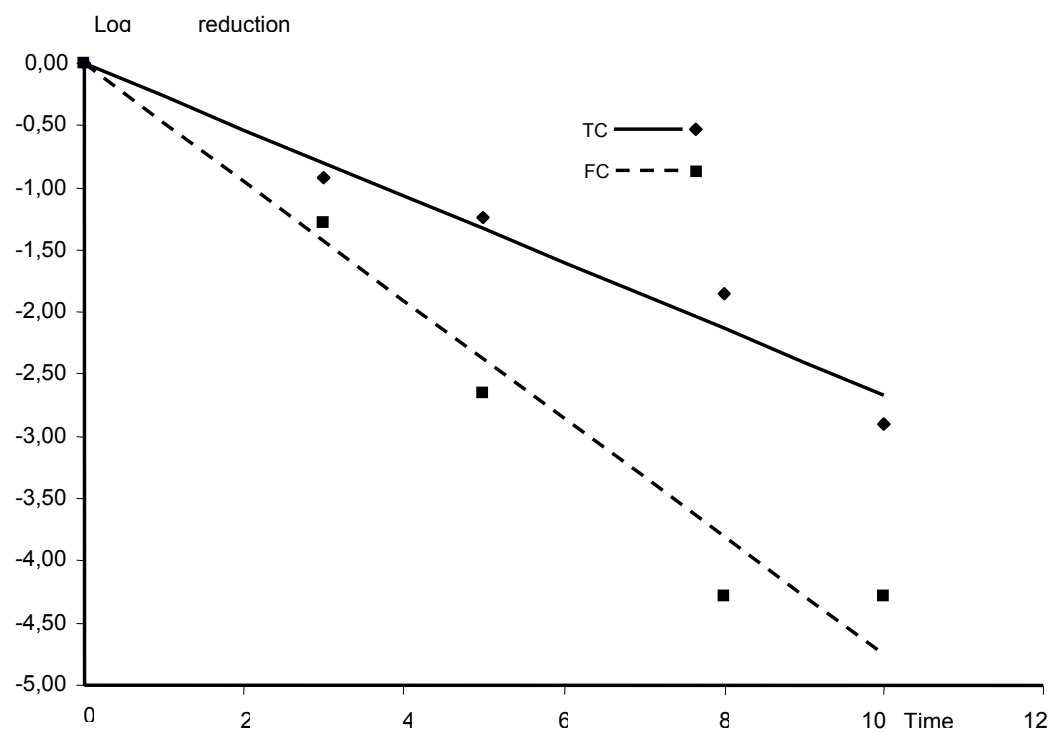

Figure 4: UV inactivation rates for total and faecal coliforms (log reduction). 
trend for total and faecal coliforms at different time exposures. It can be observed that total coliforms were more UV resistant than faecal coliforms, because a higher log reduction for faecal coliforms occurred after an exposure of 10 minutes. The equation obtained for total coliforms was $y=-0.2665 x$ $\left(R^{2}=0.9662\right)$, and for faecal coliforms $y=-0.4757 x \quad\left(R^{2}=0.9607\right)$. Both inactivation processes showed a linear portion at low UV doses. In this sense, when linear regression was calculated only with data obtained at lower UV doses $\left(<40 \mathrm{~mJ} / \mathrm{cm}^{2}\right)$, the correlation coefficient slightly improved for total coliforms, from 0.9662 up to 0.9743 , and for faecal coliforms, form 0.9607 up to 0.9907 , leading to a better fitting. Andreakis et al. [14] have reported a gradual flattening at higher UV doses, often attributed to particulate matter in the wastewater. This is consistent with the need to apply UV radiations to wastewater previously clarified, in order to avoid the effect of particles [15].

The elimination percentage for total coliforms was increasing as UV timeexposure was also increasing. None of samples irradiated during $3 \mathrm{~min}$ achieved a complete destruction of total coliforms, being $90 \%$ elimination the highest result, for sample number 18 . The same tendency was shown for other exposure periods. Faecal coliforms totally disappeared from culture media according to percentages: $33 \%$, and $50 \%$, for 3 and 5 min UV exposure, respectively, meanwhile after 8 or $10 \mathrm{~min}, 100 \%$ faecal coliforms disappeared. The effect of UV dose on bacteria inactivation is shown in Figures 5 and 6. Data fitted to an exponential equation, with correlation coefficients of 0.8167 for total coliforms, and 0.9488 for faecal coliforms. Inactivation ranges, expressed as $N / N_{0}$ (effluent/influent), for total and faecal coliforms were calculated. Both indicators showed a reciprocal regression with respect to the applied dose. A total elimination of these indicators would be achieved with doses over $95 \mathrm{~mJ} / \mathrm{cm}^{2}$.

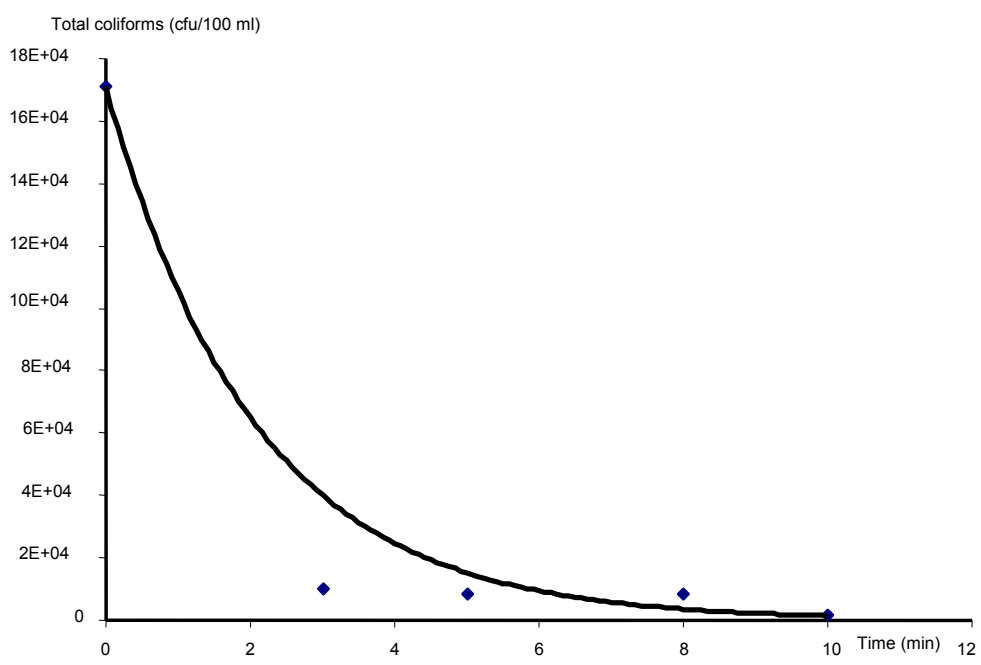

Figure 5: $\quad$ Total coliforms inactivation after UV exposure. 


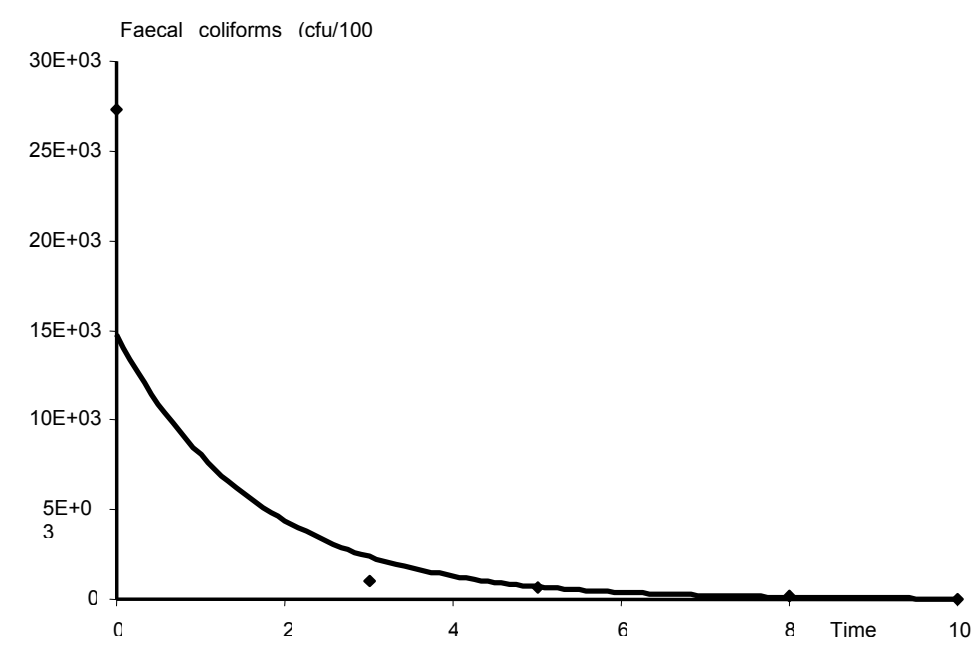

Figure 6: Faecal coliforms inactivation after UV exposure.

This ultraviolet dose is much higher than that reported by Gómez et al. [15], who indicated a value over $35 \mathrm{~mJ} / \mathrm{cm}^{2}$ for total elimination $\left(N / N_{0}=0\right)$ of faecal coliforms, E. coli and coliphages from urban wastewater. These authors used a physicochemical treatment previous to UV disinfection, obtaining effluents of excellent quality, with $99 \%$ turbidity removal. In our case, a dose of $35 \mathrm{~mJ} / \mathrm{cm}^{2}$ would eliminate only $11.23 \%$ of total coliforms, and $2.46 \%$ of faecal coliforms, as an average. These results are also consistent with those reported by Andreakis et al. [14], who found a significant increase in UV disinfection efficiency with samples sand-filtered. The implementation of UV disinfection facilities in secondary effluents needed a previous treatment in order to reduce suspended solids and turbidity in the wastewater. Sharrer et al. [16] reported a complete inactivation of coliform bacteria at approximately $77 \mathrm{~mJ} / \mathrm{cm}^{2}$, in a recirculating salmonid culture system. However, these authors indicate that total heterotrophic bacteria in the recirculating system required a UV dosage in excess of $1800 \mathrm{~mJ} /$ $\mathrm{cm}^{2}$ to achieve a not quite 2 LOG10 reduction. Macauley et al. [17] reported an irradiation time of 10 minutes for a total bacteria reduction to less than 1000 $\mathrm{cfu} / \mathrm{ml}$ in a lagoon with swine wastewater, corresponding to effective doses of 220 and $770 \mathrm{~mJ} / \mathrm{cm}^{2}$ for two lagoons. As the authors discuss, this technology is unlikely to be economically feasible, due to its high energy consumption. In our experiments, UV doses were always less than $100 \mathrm{~mJ} / \mathrm{cm}^{2}$. According to Figures 5 and 6 , a reduction down to $1000 \mathrm{cfu} / 100 \mathrm{ml}$ would need a dose over $80 \mathrm{~mJ} / \mathrm{cm}^{2}$ for total coliforms, and $33 \mathrm{~mJ} / \mathrm{cm}^{2}$ for faecal coliforms.

\section{Conclusions}

The physicochemical and microbiological parameters affecting disinfection efficiency of secondary effluents from a municipal wastewater treatment plant were investigated. The initial chlorination of the wastewater was associated with 
high turbidiy values, due to the conversion of particulate organic carbon into dissolved one. As previously reported by different authors, the nitrificationdenitrification processes probed to be sensitive to changes in $\mathrm{pH}$, with a minimum nitrate and phosphate value when $\mathrm{pH}$ ranged between 7.01-8.00. Total coliforms were more UV resistant than faecal coliforms, after an exposure of 10 minutes. Inactivation of both indicators by UV radiation appeared to follow first order reaction kinetics, with good correlation coefficients. These parameters slightly improved when linear regression was only calculated with data obtained at lower UV doses $\left(<40 \mathrm{~mJ} / \mathrm{cm}^{2}\right)$, because of a gradual flattening at higher UV doses, often attributed to particulate matter in the wastewater. Inactivation ranges, expressed as $N / N_{0}$ (effluent units / influent units), for total and faecal showed a reciprocal regression with respect to the applied dose. A total elimination of these indicators would be achieved with doses over $95 \mathrm{~mJ} / \mathrm{cm}^{2}$. Further surveys with filter processes will allow us to reduce this value, in order to increase UV transmittance and save energy.

\section{Acknowledgement}

This study was supported by the Instituto Euromediterráneo de Hidrotecnia, Project number PI 0303 IEH.

\section{References}

[1] Lazarova, V., Savoye, P., Janex, M.I., Blatchley III, E.R. \& Pommepuy, M., Advanced wastewater disinfection technologies: state of the art and perspectives. Water Science and Technology, 40, pp. 203-213, 1999.

[2] Sommer, R., Haider, T., Cabaj, A., Pribil, W. \& Lhotsky, M., Time dose reciprocity in UV disinfection of water. Water Science and Technology, 38(12), pp. 145-150, 1998.

[3] APHA, AWWA, and WEF, Standard methods for the Examination of Water and Wastewater, 19 ed., American Public Health Association, Washington, DC., 1995.

[4] Tran, M.T.T. \& Farid, M., Ultraviolet treatment of orange juice. Innovative Food Science and Emerging Technologies, 5, pp. 495-502, 2004.

[5] Van der Toorn, J.D., A biological approach to water purification. Aquatic Mammals, 13(3), pp. 83-92, 1987.

[6] Diyamandoglu, V., Mariñas, B.J. \& Selleck, R.E., Stoichiometry and kinetics of the reaction of nitrite with free chlorine in aqueous solutions. Environmental Science and Technology, 24(11), pp. 1711-1716, 1990.

[7] Mulkerrins, D., Dobson, A.D.W. \& Colleran, E., Parameters affecting biological phosphate removal from wastewaters. Environment International, 30, pp. 249-259, 2004.

[8] Surampalli, R.Y., Tyagi, R.D., Scheible, O.K. \& Heidman, J.A., Nitrification, denitrification and phosphorous removal in sequential batch reactors. Biosources Technology, 61(2), pp. 151-157, 1997. 
[9] Hosni, K., Ben Moussa, S. \& Ben Amor, M., Conditions influencing the removal of phosphate from synthetic wastewater: influence of the ionic composition. Desalination, 206, pp. 279-285, 2007.

[10] Irdemez, S.; Demircioglu, N. \& Yildiz, Y.S., The effects of $\mathrm{pH}$ on phosphate removal from wastewater by electrocoagulation with iron plate electrodes. Journal of Hazardous Materials, B137, pp. 1231-1235, 2006.

[11] Uncles, R.J., Frickers, P.E. \& Harris, C., Dissolved nutrients in the Tweed Estuary, UK: inputs, distributions and effects of residence time. The Science of Total Environment, 314-316, pp. 727-736, 2003.

[12] Lazarova, V., Savoye, P., Janex, M.I., Blatchley III, E.R. \& Pommepuy, M., Advanced wastewater disinfection technologies: state of the art and perspectives. Water Science and Technology, 40(4-5), pp. 203-213, 1999.

[13] Tchobanoglous, G., Burton, F.L. \& Stensel, H.D., Disinfection processes (Chapter 12). Wastewater Engineering: Treatment and Reuse, ed. G. Tchobanoglous, F.L. Burton \& H.D. Stensel, McGraw-Hill: Boston, pp. 1217-1344, 2003.

[14] Andreakis, A., Mamais, D., Christoulas, D. \& Kabylafka, S., Ultraviolet disinfection of secondary and tertiary effluent in the Mediterranean region. Water Science and Technology, 40(4-5), pp. 253-260, 1999.

[15] Gómez, A., Plaza, F., Garralón, G., Pérez, J. \& Gómez, M.A., A comparative study of tertiary wastewater treatment by physico-chemicalUV process and macrofiltration-ultrafiltratioin technologies. Desalination, 202, pp. 369-376, 2007.

[16] Sharrer, M.J., Summerfelt, S.T., Bullock, G.L., Gleason, L.E. \& Taeuber, J., Inactivation of bacteria using ultraviolet irradiation in a recirculating salmonid culture system. Aquacultural Engineering, 33, pp. 135-149, 2005.

[17] Macauley, J.J., Qiang, Z., Adams, C.D., Surampalli, R. \& Mormile, M.R., Disinfection of swine wastewater using chlorine, ultraviolet light and ozone. Water Research, 40, pp. 2017-2026, 2006. 